\title{
Effect of increasing levels of threonine relative to lysine on the performance and meat quality of finishing pigs
}

\author{
Santi Devi Upadhaya ${ }^{1}$, Sang Seon Lee ${ }^{1}$, Sung Giu Jin ${ }^{2}$, Zhenlong $\mathrm{Wu}^{3}$, and In Ho Kim ${ }^{1}$,*
}

* Corresponding Author: In Ho Kim Tel: +82-41-550-3652; Fax: +82-41-565-2949,

E-mail: inhokim@dankook.ac.kr

1 Department of Animal Resource and Science, Dankook University, Cheonan 31116, Korea

Department of Pharmaceutical Engineering Dankook University, Cheonan 31116, Korea

${ }^{3}$ State Key Laboratory of Animal Nutrition, Department of Animal Nutrition and Feed

Science, China Agricultural University, Beijing 100193, China

ORCID

Santi Devi Upadhaya

https://orcid.org/0000-0002-3801-4964

Sang Seon Lee

https://orcid.org/0000-0002-9823-9241

Sung Giu Jin

https://orcid.org/0000-0003-1558-5155 Zhenlong Wu

https://orcid.org/0000-0001-9700-8874 In Ho Kim

https://orcid.org/0000-0001-6652-2504

Submitted Feb 21, 2021; Revised Apr 21, 2021; Accepted May 23, 2021
Objective: The present study aimed to evaluate the effects of varying standardized ileal digestible lysine:threonine (SID Lys:Thr) ratio in the diet on the performance and meat quality of finishing pigs.

Methods: In total 192 crossbred pigs ([Landrace $\times$ Yorkshire $] \times$ Duroc, 17 weeks old), with an initial body weight (BW) of $70.6 \pm 3.9 \mathrm{~kg}$ were used in an 8 -wk trial. Pigs were randomly allotted to one of six dietary treatments based on their initial BW and sex (8 replications; 4 pigs per pen, 2 barrows and 2 gilts). The pigs in the 6 treatments were fed diets having different SID Lys:Thr ratios such as 1:0.65, 1:0.66, 1:0.67, 1:0.68, 1:0.69, and 1:0.70.

Results: A linear increment $(\mathrm{p}<0.05)$ in average daily gain $(\mathrm{ADG})$ and trends in reduction in feed conversion ratio (FCR) were observed during day 29 to 56 of the experiment and the apparent total tract digestibility (ATTD) of dry matter tended to increase linearly ( $\mathrm{p}=$ 0.094) at the end of the experiment (day 56) with the increase in the dietary SID Lys:Thr ratios. The backfat thickness and lean percentage increased (linear effect, $\mathrm{p}<0.05$ ) on day 28. In addition, at day 56 , a linear $(\mathrm{p}<0.05)$ increment in lean percentage was observed. Significant quadratic responses $(\mathrm{p}=0.02)$ for $\mathrm{pH}$ and drip loss at day $7(\mathrm{p}=0.02)$, a linear increase $(\mathrm{p}<0.05)$ in cooking loss and drip loss at day 7 , and a trend in quadratic response $(p=0.07)$ in the lightness of meat color $\left(L^{*}\right)$ were observed, whereas other meat quality indices were unaffected by varying the SID Lys:Thr ratios.

Conclusion: The SID Lys:Thr ratio for maximum ADG, minimum FCR and enhanced digestibility was found to be 0.70 . However, for carcass trait and meat quality, the SID Lys:Thr ratio of 0.65 was enough.

Keywords: Finishing Pig; Lysine; Meat Quality; Performance; Threonine Ratio

\section{INTRODUCTION}

Threonine is an essential amino acid (AA) that is not synthesized by animals and is required for both maintenance and growth. It is the primary AA constituent of immunoglobulins and represents the proteins that are secreted in a significant proportion by the small intestine [1]. A sufficient intake of dietary threonine (Thr) has been reported to be particularly important for maintaining the integrity of the gut barrier because of its role in the synthesis of mucosal mucin in pigs [2]. Threonine is also an important AA for protein synthesis, and its catabolism generates important metabolites such as glycine, acetyl-CoA, and pyruvate [3]. The ratio for some AAs relative to lysine (Lys) is assumed to increase with increasing body weight (BW), because of varying requirements for maintenance and production. For instance, the Thr requirement for maintenance has been suggested to be relatively high and varies with the age, rate of growth or protein accretion [4,5]. The ileal digestibility of AAs among different feedstuffs varies widely [6,7]. The possible reason for the variation in $\mathrm{Thr}$ requirement may be that some of the older studies were based on the concentration 
of total Thr in the diet rather than the ileal digestible Thr concentration $[8,9]$. By using AA ideal protein ratios, it is assumed that the amount of AAs provided to animals is enough to meet the requirements for maintenance and growth without creating a surplus or deficiency [10]. For reducing nitrogen (N) excretion and feed costs, the concept of utilizing ideal protein is widely accepted as an effective tool. A previous study suggested that the ideal AA ratios for Thr range from $65 \%$ of Lys for 5 to $20 \mathrm{~kg}$ live weight to $70 \%$ of Lys requirement for 50 to $100 \mathrm{~kg}$ live weight [11]. This implies different AA requirements for different BWs. In another study by Plitzner et al [12], the total dietary Lys:Thr ratio was estimated to be 1:0.65 or higher for modern crossbred finishing pigs ( 68 to $113 \mathrm{~kg}$ ) based on the concept of ideal protein. The results of published studies give a wide range for Thr requirements of pigs in all stages of growth.

The present study aimed to evaluate the effects of increasing the level of Thr by $1 \%$ unit from $65 \%$ of Lys requirements in CON/basal diet to 5 different levels $(66 \%, 67 \%, 68 \%, 69 \%$, and $70 \%$ of Lys) to evaluate the optimal SID Lys:Thr ratio which enhances the performance and carcass quality of finishing pigs

\section{MATERIALS AND METHODS}

\section{Animal care}

This study was undertaken following the guidelines of the Research Policy of Dankook University. The protocol for this study (DK-2-2004) was approved by the Animal Care and Use Committees of Dankook University, Cheonan, South, Korea.

\section{Animals and diets}

A total of 192 crossbred pigs ([Landrace $\times$ Yorkshire $] \times$ Duroc, 17 weeks old) with an initial BW of $70.6 \pm 3.9 \mathrm{~kg}$ were used in an 8-wk trial. Pigs were randomly allotted to one of six dietary treatments (each $n=32$ ) based on their initial BW and sex (8 replications; 4 pigs per pen, 2 barrows and 2 gilts). The pigs in the 6 treatments were fed with diets having different Lys:Thr ratios: 1:0.65, 1:0.66, 1:0.67, 1:0.68, 1:0.69, and 1:0.70 by supplementing the diet with increasing levels of synthetic Thr. Threonine used in the present study was purchased from NL FARM, 318, RIT center, Gyeonggi Technopark, Ansan-si, Gyeonggi-do, Republic of Korea.

The diets were formulated to be isoenergetic and isonitrogenous and to meet or exceed the NRC [13] nutrient requirements (Table 1). All pigs were housed in an environmentally controlled room with a slatted plastic floor. Each pen was equipped with a 1-sided self-feeder and a nipple waterer to allow the pigs ad libitum access to feed and water throughout the experimental period.

\section{Growth performance}

Feed intake per pen was recorded daily, individual pig BW was measured on the initial day, at the end of week 4 (day 28 ) and week 8 (day 56) of the experiment, the feed consumption, and pig BW were used to monitor ADG, average daily feed intake (ADFI) and feed conversion ratio (FCR).

\section{Nutrient digestibility}

The apparent total tract digestibility (ATTD) of nutrients was measured at the end of the experimental period. Chromium oxide $\left(\mathrm{Cr}_{2} \mathrm{O}_{3}, 0.25 \%\right)$, an indigestible marker was added to the diet 7 days prior to fecal collection to calculate the nutrient digestibility. Fecal samples were randomly collected from at least two pigs/pen $(n=16$ per treatment $)$ via the rectal massage and were pooled by pen. Based on treatment, all the feed and fecal samples were dried $\left(70^{\circ} \mathrm{C}\right.$ for $\left.72 \mathrm{~h}\right)$ and finely ground to be able to pass through a $1 \mathrm{~mm}$ screen. Then fecal samples were analyzed for dry matter (DM) and $\mathrm{N}$ following the procedure outlined by AOAC International [14]. The gross energy was determined by measuring the heat of combustion by Parr 6400 oxygen bomb calorimeter (Parr Instrument Co., Moline, IL, USA). Chromium was analyzed via UV/VIS spectrophotometer (Optizen POP, Daejeon, Korea). For calculating the ATTD of the nutrients, we used the following formula: Digestibility $=1-([\mathrm{Nf} \times \mathrm{Cd}] /[\mathrm{Nd} \times \mathrm{Cf}])$ $\times 100$, where $\mathrm{Nf}=$ concentration of nutrient in feces $(\% \mathrm{DM})$, $\mathrm{Nd}=$ concentration of nutrient in the diet, $\mathrm{Cd}=$ concentration of chromium in the diet and $\mathrm{Cf}=$ concentration of chromium in the feces.

Feed samples were analyzed for crude protein $(\mathrm{N} \times 6.25$; method 988.05), crude fat (method 954.02), crude fiber (method 962.09), crude ash (method 942.05), calcium (method 984.01), phosphorous (method 965.17), and AAs (method 982.30E) following the procedures established by AOAC International [14].

\section{Backfat thickness and lean percentage}

The back fat thickness and lean percentage of all live pigs ( $\mathrm{n}$ $=32$ per treatment) were measured $5 \mathrm{~cm}$ from the righthand side of the midline from 3 different sites (shoulder, mid back, and loin at a position directly above the point of elbow, last rib, and last lumbar vertebra, respectively) before the commencement and at the end of week 4 and week 8 of the experiment using a real-time ultrasound instrument (Piglog 105; SFK Technology, Herlev, Denmark [15]). The mean value was taken and used for subsequent statistical analysis.

\section{Meat quality}

At the end of the experiment, animals were transported to a local abattoir and slaughtered. After slaughter, carcass weight and backfat thickness were measured from all pigs. Ten pigs 
Table 1. Ingredient and nutrient composition of experimental diets for finishing pigs (as fed-basis)

\begin{tabular}{|c|c|c|c|c|c|c|}
\hline \multirow{3}{*}{ Items } & \multicolumn{6}{|c|}{ Level of Thr (\% of requirements) } \\
\hline & 65 & 66 & 67 & 68 & 69 & 70 \\
\hline & $\operatorname{CON}^{1)}$ & Thr1 ${ }^{1)}$ & Thr2 ${ }^{1)}$ & Thr3 ${ }^{1)}$ & Thr4 ${ }^{1)}$ & Thr5 ${ }^{1)}$ \\
\hline \multicolumn{7}{|l|}{ Ingredients (\%) } \\
\hline Corn & 76.785 & 76.776 & 76.758 & 76.739 & 76.731 & 76.712 \\
\hline Soybean meal (48\%) & 15.71 & 15.71 & 15.71 & 15.72 & 15.72 & 15.72 \\
\hline Tallow & 2.46 & 2.46 & 2.47 & 2.47 & 2.47 & 2.48 \\
\hline Molasses & 2 & 2 & 2 & 2 & 2 & 2 \\
\hline Dicalcium phosphate & 1.35 & 1.35 & 1.35 & 1.35 & 1.35 & 1.35 \\
\hline Limestone & 0.56 & 0.56 & 0.56 & 0.56 & 0.56 & 0.56 \\
\hline Salt & 0.3 & 0.3 & 0.3 & 0.3 & 0.3 & 0.3 \\
\hline Methionine (99\%) & 0.02 & 0.02 & 0.02 & 0.02 & 0.02 & 0.02 \\
\hline Lysine & 0.29 & 0.29 & 0.29 & 0.29 & 0.29 & 0.29 \\
\hline Threonine (99\%) & 0.045 & 0.054 & 0.062 & 0.071 & 0.079 & 0.088 \\
\hline Mineral mix & 0.2 & 0.2 & 0.2 & 0.2 & 0.2 & 0.2 \\
\hline Vitamin mix $^{3)}$ & 0.2 & 0.2 & 0.2 & 0.2 & 0.2 & 0.2 \\
\hline Phytase & 0.05 & 0.05 & 0.05 & 0.05 & 0.05 & 0.05 \\
\hline Choline (25\%) & 0.03 & 0.03 & 0.03 & 0.03 & 0.03 & 0.03 \\
\hline Total & 100 & 100 & 100 & 100 & 100 & 100 \\
\hline \multicolumn{7}{|l|}{ Calculated composition (\%) } \\
\hline Metabolizable energy (kcal/kg) & 3,300 & 3,300 & 3,300 & 3,300 & 3,300 & 3,300 \\
\hline Crude protein & 14 & 14 & 14 & 14 & 14 & 14 \\
\hline $\mathrm{Ca}$ & 0.6 & 0.6 & 0.6 & 0.6 & 0.6 & 0.6 \\
\hline$P$ & 0.55 & 0.55 & 0.55 & 0.55 & 0.55 & 0.55 \\
\hline Lys & 0.86 & 0.86 & 0.86 & 0.86 & 0.86 & 0.86 \\
\hline Met & 0.25 & 0.25 & 0.25 & 0.25 & 0.25 & 0.25 \\
\hline Thr & 0.559 & 0.568 & 0.576 & 0.585 & 0.593 & 0.602 \\
\hline Trp & 0.15 & 0.15 & 0.15 & 0.15 & 0.15 & 0.15 \\
\hline Crude fat & 5.32 & 5.32 & 5.33 & 5.33 & 5.33 & 5.34 \\
\hline Crude fiber & 2.35 & 2.35 & 2.35 & 2.35 & 2.35 & 2.35 \\
\hline Crude ash & 4.36 & 4.36 & 4.36 & 4.36 & 4.36 & 4.36 \\
\hline \multicolumn{7}{|l|}{ Analyzed composition ${ }^{4)}(\%)$} \\
\hline Crude protein & 13.96 & 13.95 & 13.94 & 14.03 & 13.93 & 13.98 \\
\hline $\mathrm{Ca}$ & 0.60 & 0.58 & 0.62 & 0.59 & 0.61 & 0.58 \\
\hline$P$ & 0.55 & 0.54 & 0.55 & 0.53 & 0.55 & 0.53 \\
\hline Lys & 0.86 & 0.87 & 0.85 & 0.84 & 0.86 & 0.83 \\
\hline Met & 0.22 & 0.24 & 0.25 & 0.25 & 0.24 & 0.23 \\
\hline Thr & 0.560 & 0.567 & 0.578 & 0.585 & 0.593 & 0.601 \\
\hline Trp & 0.15 & 0.16 & 0.14 & 0.14 & 0.15 & 0.15 \\
\hline Crude fat & 5.32 & 5.31 & 5.33 & 5.32 & 5.34 & 5.34 \\
\hline Crude fiber & 2.35 & 2.36 & 2.33 & 2.36 & 2.32 & 2.34 \\
\hline Crude ash & 4.32 & 4.36 & 4.35 & 4.33 & 4.35 & 4.36 \\
\hline
\end{tabular}

1) $\mathrm{CON}$, lysine:threonine $=1: 0.65 ; \mathrm{Thr}$, lysine:threonine $=1: 0.66 ;$ Thr 2, lysine:threonine $=1: 0.67$; Thr 3, lysine:threonine $=1: 0.68 ;$ Thr 4, lysine:threonine $=$ 1:0.69; Thr 5, lysine:threonine $=1: 0.70$.

2) Provided per kg diet: Fe, $115 \mathrm{mg}$ as ferrous sulfate; Cu, 70 mg as copper sulfate; Mn, 20 mg as manganese oxide; Zn, 60 mg as zinc oxide; I, 0.5 mg as potassium iodide; and Se, $0.3 \mathrm{mg}$ as sodium selenite.

3) Provided per kilograms of diet: vitamin $A, 13,000 \mathrm{IU}$; vitamin $\mathrm{D}_{3}, 1,700 \mathrm{IU}$; vitamin $\mathrm{E}, 60 \mathrm{IU}$; vitamin $\mathrm{K}_{3}, 5 \mathrm{mg}$; vitamin $\mathrm{B}_{1}, 4.2$ mg; vitamin $\mathrm{B}_{2}, 19 \mathrm{mg}$; vitamin $\mathrm{B}_{6}, 6.7 \mathrm{mg}$; vitamin $\mathrm{B}_{12}, 0.05 \mathrm{mg}$; biotin, $0.34 \mathrm{mg}$; folic acid, $2.1 \mathrm{mg}$; niacin, $55 \mathrm{mg}$; D-calcium pantothenate, $45 \mathrm{mg}$.

${ }^{4)}$ Data are the mean of duplicate analyses of each ingredient.

per treatment (total 60 pigs) were randomly selected prior to the transport to the abattoir for meat quality assessment. After slaughter, carcasses from the selected pigs were placed in a conventional chiller at $4^{\circ} \mathrm{C}$. Then carcasses were fabricated into primal cuts after a 24 -h chilling period. Meat samples including lean, and fat were taken via perpendicular cut loins into 2-cm-thick chop beginning from the 10th and 11th ribs region and transported to the laboratory. The $\mathrm{pH}$ of muscle was measured $24 \mathrm{~h}$ after postmortem using a $\mathrm{pH}$ meter (Testo 205, Testo, Lenzkirch, Germany). Sensory evaluation was conducted by trained panelists to evaluate the color darkness, firmness and marbling of fresh loin samples using a five-point 
assessment scheme according to the procedures established by the National Pork Producers Council (NPPC) [16]. Immediately after the subjective tests were conducted, meat color of the longissimus muscle (LM) as lightness $\left(\mathrm{L}^{*}\right)$, redness $\left(\mathrm{a}^{*}\right)$, and yellowness $\left(\mathrm{b}^{*}\right)$, was determined using a Minolta Chroma Meter (CR-210, Minolta, Tokyo, Japan) to evaluate the freshly cut surface after $30 \mathrm{~min}$ of blooming at $4^{\circ} \mathrm{C}$. Waterholding capacity (WHC) was measured using methods of Kauffman et al [17]. Briefly, a 0.2-g sample was pressed at 3,000 psi for $3 \mathrm{~min}$ onto laboratory grade $125-\mathrm{mm}$-diameter filter paper. The areas of pressed sample and expressed moisture were delineated and determined with a digitizing area-line sensor (MT-10S; M. T. Precision Co. Ltd, 123 Tokyo, Japan). A ratio of water area: meat area was calculated to measure WHC, with smaller ratio indicating higher WHC. The LM area was measured by tracing the LM surface at the 10th rib, which also used the mentioned above digitizing area-line sensor. Cook loss was determined as described previously by Sullivan et al [18]. Briefly, $5 \mathrm{~g}$ of meat sample were heat-treated in plastic bags separately in a water bath $\left(100^{\circ} \mathrm{C}\right)$ for $5 \mathrm{~min}$. Samples were cooled at room temperature. Cooking loss was calculated as (sample weight before cooking - sample weight after cooking)/sample weight before cooking $\times 100$. According to the plastic bag method described by Honikel [19], drip loss was measured using $\sim 4 \mathrm{~g}$ of meat sample.

\section{Statistical analysis}

Data were analyzed as a completely randomized-block design using the general linear model procedures (SAS Institute Inc., Cary, NC, USA). The pen served as the experimental unit for all response criteria except meat quality wherein individual pigs were the experimental unit. Variability in data is expressed as standard errors of the mean. Linear and quadratic polynomial contrasts were performed to determine the effects of the different SID Lys:Thr ratios in the diet, with $\mathrm{p}<0.05$ indicating significance and $\mathrm{p}<0.10$ indicating trends.

\section{RESULTS}

\section{Growth performance}

Increasing the SID Lys:Thr ratio of finishing diets did not exert any significant effects in ADG, ADFI, and FCR during day 1 to 28 and in the overall experiment period although numerical increase in ADG and a slight reduction in FCR was observed during these periods. However, increasing the SID Lys:Thr ratio of finishing diets led to a numerical increase in BW during the end of the experiment. In addition, a significant linear increment in ADG $(\mathrm{p}<0.05)$ and trends in reduction in FCR but no effect on ADFI was observed during day 29 to 56 (Table 2).

\section{Apparent total-tract nutrient digestibility}

The ATTD of DM tended to increase linearly $(p=0.094)$ at the end of the experiment (day 56) with the increase in the SID Lys:Thr ratio of finishing diets. The ATTD of N and energy remained unaffected with the increase in SID Lys:Thr ratio although there were numerical increments in digest-

Table 2. Effect of varying dietary Lys:Thr ratios on growth performance in finishing pigs ${ }^{1)}$

\begin{tabular}{|c|c|c|c|c|c|c|c|c|c|}
\hline \multirow{3}{*}{ Items } & \multicolumn{6}{|c|}{ Level of Thr (\% of Lys requirements) } & \multirow{3}{*}{ SEM } & \multirow{2}{*}{\multicolumn{2}{|c|}{$\mathrm{p}$-value }} \\
\hline & \multirow{2}{*}{\begin{tabular}{|c|}
65 \\
CON $^{1)}$
\end{tabular}} & \multirow{2}{*}{\begin{tabular}{|c|}
66 \\
Thr1 ${ }^{1)}$
\end{tabular}} & \multirow{2}{*}{\begin{tabular}{|c|}
67 \\
Thr2
\end{tabular}} & \multirow{2}{*}{\begin{tabular}{|c|}
68 \\
Thr3'
\end{tabular}} & \multirow{2}{*}{\begin{tabular}{|c|}
69 \\
Thr4 ${ }^{1)}$
\end{tabular}} & \multirow{2}{*}{\begin{tabular}{|c|}
70 \\
Thr5
\end{tabular}} & & & \\
\hline & & & & & & & & Linear & Quadratic \\
\hline \multicolumn{10}{|c|}{ Body weight (kg) } \\
\hline Initial & 70.54 & 70.57 & 70.56 & 70.56 & 70.56 & 70.57 & 0.04 & 0.724 & 0.989 \\
\hline Day 28 & 92.93 & 93.08 & 93.22 & 93.15 & 93.27 & 93.33 & 0.39 & 0.451 & 0.887 \\
\hline Day 56 & 115.71 & 116.04 & 116.31 & 116.39 & 116.63 & 117.45 & 0.79 & 0.119 & 0.746 \\
\hline \multicolumn{10}{|l|}{ Day 1 to 28} \\
\hline$A D G(g)$ & 800.0 & 804.0 & 809.0 & 807.0 & 811.0 & 813.0 & 13.66 & 0.469 & 0.883 \\
\hline ADFI (g) & 2,231 & 2,233 & 2,237 & 2,236 & 2,239 & 2,243 & 23.31 & 0.710 & 0.963 \\
\hline FCR & 2.796 & 2.781 & 2.767 & 2.775 & 2.761 & 2.760 & 0.036 & 0.443 & 0.823 \\
\hline \multicolumn{10}{|c|}{ Day 29 to 56} \\
\hline ADG (g) & 814 & 820 & 825 & 830 & 834 & 862 & 14.55 & 0.023 & 0.448 \\
\hline ADFI (g) & 2690 & 2694 & 2702 & 2708 & 2717 & 2744 & 35.02 & 0.246 & 0.698 \\
\hline FCR & 3.309 & 3.288 & 3.280 & 3.268 & 3.260 & 3.190 & 0.045 & 0.075 & 0.561 \\
\hline \multicolumn{10}{|c|}{ Overall (Day 1 to 56 ) } \\
\hline ADG (g) & 807 & 812 & 817 & 818 & 823 & 837 & 14.04 & 0.122 & 0.746 \\
\hline$A D F I(q)$ & 2,461 & 2,464 & 2,469 & 2,472 & 2,478 & 2,494 & 25.06 & 0.323 & 0.77 \\
\hline FCR & 3.055 & 3.038 & 3.026 & 3.025 & 3.015 & 2.981 & 0.035 & 0.145 & 0.813 \\
\hline
\end{tabular}

Values represent the means of eight pens with four pigs per pen.

SEM, standard error of means; ADG, average daily gain; ADFI, average daily feed intake; FCR, feed conversion ratio.

1) $\mathrm{CON}$, lysine:threonine = 1:0.65; Thr1, lysine:threonine = 1:0.66; Thr2, lysine:threonine = 1:0.67; Thr3, lysine:threonine $=1: 0.68$; Thr4, lysine:threonine $=$

1:0.69); Thr5, lysine:threonine $=1: 0.70$. 
ibility values (Table 3 ).

\section{Backfat and lean percentage}

The backfat thickness and lean percentage increased significantly (linear effect, $\mathrm{p}<0.05$ ) with the increase in the SID Lys:Thr ratio of finishing diets on day 28. In addition, at day 56 , a trend in a linear increase in backfat thickness $(\mathrm{p}=0.073)$ and a significant linear $(\mathrm{p}<0.05)$ increment in lean percentage was observed as the ratio of SID Lys:Thr increased in the diet of finishing pigs (Table 4).

\section{Carcass trait and meat quality}

There were no significant effects on carcass weight and backfat thickness of pigs at slaughter by increasing the SID Lys:Thr ratio in finishing diet. Significant quadratic responses $(\mathrm{p}=$ $0.02)$ for $\mathrm{pH}$ and drip loss at day $7(\mathrm{p}=0.02)$, a significant linear increase $(\mathrm{p}<0.05)$ in cooking loss and drip loss at day 7 , and a trend in quadratic response $(\mathrm{p}=0.07)$ in the lightness of meat color $\left(\mathrm{L}^{*}\right)$ were observed, whereas other meat quality indices were unaffected by varying SID Lys:Thr ratio in finishing diet (Table 5).

\section{DISCUSSION}

The objective of the present study was to determine the effects of increasing dietary SID Thr:Lys ratio into isoenergetic and isonitrogenous finishing pig diets on their performance and carcass quality. Several previous studies have reported the varying optimal Lys:Thr ratios. For instance, a study by Xie et al [20] using a linear-plateau model showed that the optimum SID Thr:Lys ratios for maximal weight gain and minimal feed conversion were $67 \%$ and $71 \%$, respectively in finishing pigs weighing $72 \mathrm{~kg}$ at the start of the experiment when fed low crude protein diets ad libitum. In another study, $\mathrm{Ma}$ et al [21] reported that 90 to $118 \mathrm{~kg}$ gilts when fed low crude protein diets ad libitum, the optimum SID Thr:Lys ratios to maximize average daily gain and to minimize FCR were $61 \%$ and $63 \%$, respectively, using a linear-plateau model. Based on recent literature, van der Peet-Schwering and Bikker [22] recommended a minimum SID Thr:Lys ratio from $66 \%$ to $68 \%$ for growing and finishing pigs which agrees with the findings of Plitzner et al [23]. Results from the present study have shown that dietary Thr concentration of $7.0 \mathrm{~g} / \mathrm{kg}$ im-

Table 3. Effect of varying dietary Lys:Thr ratios on nutrient digestibility in finishing pigs

\begin{tabular}{|c|c|c|c|c|c|c|c|c|c|}
\hline \multirow{3}{*}{ Items (\%) } & \multicolumn{6}{|c|}{ Level of Thr (\% of Lys requirements) } & \multirow{3}{*}{ SEM } & \multirow{2}{*}{\multicolumn{2}{|c|}{ p-value }} \\
\hline & \multirow{2}{*}{$\begin{array}{c}65 \\
\operatorname{CON}^{1)}\end{array}$} & \multirow{2}{*}{$\begin{array}{c}66 \\
\text { Thr1 }^{1)}\end{array}$} & \multirow{2}{*}{$\begin{array}{c}67 \\
\text { Thr2 }\end{array}$} & \multirow{2}{*}{$\begin{array}{c}68 \\
\text { Thr3 }^{1)}\end{array}$} & \multirow{2}{*}{$\begin{array}{c}69 \\
\text { Thr4 }\end{array}$} & \multirow{2}{*}{$\begin{array}{c}70 \\
\text { Thr5 }^{1)}\end{array}$} & & & \\
\hline & & & & & & & & Linear & Quadratic \\
\hline Dry matter & 71.02 & 70.38 & 71.81 & 71.31 & 72.83 & 73.95 & 1.50 & 0.094 & 0.506 \\
\hline Nitrogen & 69.56 & 69.06 & 70.26 & 70.00 & 70.72 & 71.40 & 1.84 & 0.373 & 0.814 \\
\hline Digestible energy & 71.23 & 70.38 & 72.24 & 71.11 & 72.46 & 72.56 & 1.66 & 0.401 & 0.86 \\
\hline
\end{tabular}

Values represent the means of eight pens with two pigs per pen.

SEM, standard error of means.

${ }^{1)} \mathrm{CON}$, lysine:threonine $=1: 0.65 ; \mathrm{Thr}$, lysine:threonine $=1: 0.66 ; \mathrm{Thr}$, lysine:threonine $=1: 0.67 ; \mathrm{Thr}$, lysine:threonine $=1: 0.68 ;$ Thr4, lysine:threonine $=$ 1:0.69); Thr5, lysine:threonine = 1:0.70.

Table 4. Effect of varying dietary Lys:Thr ratios on backfat thickness and lean percentage in finishing pigs

\begin{tabular}{|c|c|c|c|c|c|c|c|c|c|}
\hline \multirow{3}{*}{ Items } & \multicolumn{6}{|c|}{ Level of Thr (\% of Lys requirements) } & \multirow{3}{*}{ SEM } & \multirow{2}{*}{\multicolumn{2}{|c|}{ p-value }} \\
\hline & \multirow{2}{*}{$\begin{array}{c}65 \\
\text { CON }^{1)}\end{array}$} & \multirow{2}{*}{$\begin{array}{c}66 \\
\text { Thr1 }{ }^{1)}\end{array}$} & \multirow{2}{*}{$\begin{array}{c}67 \\
\text { Thr2 }\end{array}$} & \multirow{2}{*}{$\begin{array}{c}68 \\
\text { Thr3 }^{1)}\end{array}$} & \multirow{2}{*}{$\begin{array}{c}69 \\
\text { Thr4 }\end{array}$} & \multirow{2}{*}{$\begin{array}{c}70 \\
\text { Thr5 }\end{array}$} & & & \\
\hline & & & & & & & & Linear & Quadratic \\
\hline \multicolumn{10}{|l|}{ Initial } \\
\hline Backfat thickness (mm) & 12.05 & 11.94 & 11.96 & 11.81 & 11.99 & 12.03 & 0.12 & 0.916 & 0.212 \\
\hline Lean (\%) & 59.35 & 58.78 & 58.95 & 58.69 & 59.02 & 59.03 & 0.23 & 0.538 & 0.102 \\
\hline \multicolumn{10}{|l|}{ Week 4} \\
\hline Backfat thickness (mm) & 14.90 & 15.00 & 15.20 & 15.10 & 15.30 & 15.40 & 0.15 & 0.024 & 0.998 \\
\hline Lean $(\%)$ & 55.68 & 55.80 & 55.96 & 55.94 & 56.08 & 56.17 & 0.19 & 0.044 & 0.881 \\
\hline \multicolumn{10}{|l|}{ Week 8} \\
\hline Backfat thickness (mm) & 17.68 & 17.91 & 17.84 & 18.01 & 18.01 & 18.05 & 0.15 & 0.0739 & 0.634 \\
\hline Lean (\%) & 52.06 & 52.60 & 52.24 & 52.74 & 52.75 & 52.88 & 0.29 & 0.045 & 0.835 \\
\hline
\end{tabular}

Values represent the means of eight pens with four pigs per pen.

SEM, standard error of means.

1) $\mathrm{CON}$, lysine:threonine = 1:0.65; Thr1, lysine:threonine = 1:0.66; Thr2, lysine:threonine = 1:0.67; Thr3, lysine:threonine = 1:0.68; Thr4, lysin:threonine $=1$ :

0.69; Thr5, lysine:threonine $=1: 0.70$. 
Table 5. Effect of varying dietary Lys:Thr ratios on carcass trait and meat quality in finishing pigs

\begin{tabular}{|c|c|c|c|c|c|c|c|c|c|}
\hline \multirow{3}{*}{ Items } & \multicolumn{6}{|c|}{ Level of Thr (\% of Lys requirements) } & \multirow{3}{*}{ SEM } & \multirow{2}{*}{\multicolumn{2}{|c|}{ p-value }} \\
\hline & \multirow{2}{*}{$\begin{array}{c}65 \\
\mathrm{CON}^{1)}\end{array}$} & \multirow{2}{*}{$\begin{array}{c}66 \\
\text { Thr1 }{ }^{1)}\end{array}$} & \multirow{2}{*}{$\begin{array}{c}67 \\
\text { Thr2 }^{1)}\end{array}$} & \multirow{2}{*}{$\begin{array}{c}68 \\
\text { Thr3 }^{1)}\end{array}$} & \multirow{2}{*}{$\begin{array}{c}69 \\
\text { Thr4 }\end{array}$} & \multirow{2}{*}{$\begin{array}{c}70 \\
\text { Thr5 }\end{array}$} & & & \\
\hline & & & & & & & & Linear & Quadratic \\
\hline Backfat thickness (mm) & 18.56 & 19.41 & 19.19 & 19.25 & 19.13 & 19.66 & 0.65 & 0.387 & 0.841 \\
\hline $\mathrm{pH}$ & 5.36 & 5.4 & 5.42 & 5.45 & 5.33 & 5.35 & 0.016 & 0.129 & 0.002 \\
\hline Water holding capacity (\%) & 38.87 & 45.56 & 39.2 & 43.73 & 37.57 & 46.05 & 1.532 & 0.206 & 0.49 \\
\hline Longissimus muscle area $\left(\mathrm{cm}^{2}\right)$ & 61.37 & 61.05 & 60.57 & 61.86 & 61.13 & 60.72 & 0.259 & 0.437 & 0.546 \\
\hline \multicolumn{10}{|l|}{ Drip loss (\%) } \\
\hline Day 1 & 4.36 & 4.67 & 4.46 & 4.6 & 4.29 & 4.96 & 0.285 & 0.401 & 0.60 \\
\hline Day 3 & 11.23 & 11.72 & 11.58 & 11.59 & 11.19 & 11.86 & 0.275 & 0.499 & 0.97 \\
\hline Day 5 & 15.80 & 16.62 & 15.54 & 15.99 & 16.19 & 16.84 & 0.314 & 0.101 & 0.15 \\
\hline Day 7 & 21.06 & 21.42 & 20.9 & 20.83 & 21.43 & 22.25 & 0.308 & 0.026 & 0.02 \\
\hline$b^{\star}$ & 4.33 & 4.35 & 4.24 & 4.51 & 4.38 & 4.15 & 0.115 & 0.584 & 0.21 \\
\hline \multicolumn{10}{|l|}{ Sensory evaluation } \\
\hline Color & 3.24 & 3.23 & 3.3 & 3.3 & 3.29 & 3.23 & 0.076 & 0.846 & 0.40 \\
\hline Firmness & 3.20 & 3.3 & 3.36 & 3.25 & 3.21 & 3.3 & 0.089 & 0.496 & 0.59 \\
\hline Marbling & 3.24 & 3.38 & 3.19 & 3.33 & 3.25 & 3.39 & 0.083 & 0.857 & 0.54 \\
\hline
\end{tabular}

Values represent the means of randomly selected 10 pigs per treatment.

SEM, sStandard error of means.

1) $\mathrm{CON}$, lysine:threonine $=1: 0.65 ; \mathrm{Thr}$, lysine:threonine $=1: 0.66 ; \mathrm{Thr}$, lysine:threonine $=1: 0.67 ; \mathrm{Thr}$, lysine:threonine $=1: 0.68 ; \mathrm{Thr}$, lysine:threonine $=$ 1:0.69; Thr5, lysine:threonine $=1: 0.70$

proved daily gains by $5.9 \%$ and the FCR by about $3.6 \%$ points compared to pigs fed the basal diet $(6.5 \mathrm{~g} / \mathrm{kg} \mathrm{Thr})$ during day 29 to 56 which is the highest values among different Thr concentrations tested in this study. A cumulative improvement in ADG and FCR by about $3.7 \%$ and $2.4 \%$ points respectively was observed in pigs receiving dietary $\mathrm{Thr}$ concentration of $7.0 \mathrm{~g} / \mathrm{kg}$ compared to those receiving basal diet (6.5 g/kg Thr). The SID Lys:Thr ratio for growth performance in the present study corroborates the findings of van Lunen [11]. The improvement in ADG and FCR in the present study the with the inclusion of $7.0 \mathrm{~g} / \mathrm{kg} \mathrm{Thr}$ in the diet might be due to the efficient absorption and utilization of other AAs at the given dose or it may be due to maintaining the adequate amount of mucosal mucins and protein synthesis [2].

Digestibility is an important factor in the measure of the nutrition value of animal feed. In the present study, increasing the SID Lys:Thr ratio in the finishing diet tended to linearly increase the DM digestibility and numerically increase in $\mathrm{N}$ and energy digestibility suggesting that $7.0 \mathrm{~g} / \mathrm{kg} \mathrm{Thr}$ is the best among the other tested concentrations. Since Thr plays an important role in mucin synthesis and barrier integrity maintenance [24,25], the inclusion of $7.0 \mathrm{~g} / \mathrm{kg} \mathrm{Thr}$ in the diet might have led to better villus surface and therefore better absorption and digestion. In addition, adequate Thr inclusion in the diet has been suggested to increase the abundance of potential beneficial bacteria which can eventually improve the nutrient digestion [26]. The trends in improvement in the digestibility of nutrients with the increase in the SID Lys:Thr ratio might have contributed in enhancing the performance of pigs.

As a pig grows towards its mature body size and weight, it deposits relatively more fat and less muscle. The backfat and lean percent measured in live pigs during week 4 and week 6 of the trial showed linear increments with the increase in the Lys:Thr ratios of finishing diet in the present study. However, Kobayashi et al [27] noted that the response to increasing level of Thr on the intramuscular fat in porcine muscle is negligible. Since there are no other reports of Lys:Thr ratios regarding their effects on backfat and lean percentage of live pigs, comparisons could not be made.

If the nutrient requirements of high genetic potential pigs are not met, it may cause them to have higher backfat at slaughter. Under appropriate feeding management and marketing time, a high- quality pork can be produced $[28,29]$. The influence of Thr supply on carcass characteristics has been reported to be much lower than the influence on growth performance [12]. In the present study, the carcass weight and backfat thickness at slaughter were unaffected by altering SID Lys:Thr ratios in the diet suggesting that $6.5 \mathrm{~g} / \mathrm{kg} \mathrm{Thr}$ was sufficient since the backfat values were the lowest at this 
concentration. Meat that exhibits low backfat and body fat, with excellent feed efficiency and meat productivity [30-32] is considered high quality. Leaner pig meat is associated with greater meat loss, lower fat, firmness, and less juiciness and flavor $[28,32,33]$. In addition, the linear response in $\mathrm{pH}$, cook loss, and quadratic response in $\mathrm{L}^{*}$ values in the present study also suggest that SID Lys:Thr ratio of $65 \%$ is appropriate for good meat quality. These observations on carcass and meat quality support the theory that the Thr requirement for growing pigs is substantially higher for maintenance than for protein accretion $[4,34]$.

\section{CONCLUSION}

Taken together from the present findings, we conclude that the dietary SID Thr requirement for both maximum average daily gain and minimum FCR was $70 \%$ of Lys requirement and an optimum SID Lys:Thr ratio was also 0.70 to maximize nutrient digestibility. However, for carcass trait and meat quality, the SID Lys:Thr ratio of 0.65 was enough. These ratios are higher than the current recommendation of 0.63 for 75 to $100 \mathrm{~kg}$ finishing pigs [13].

\section{CONFLICT OF INTEREST}

We certify that there is no conflict of interest with any financial organization regarding the material discussed in the manuscript.

\section{ACKNOWLEDGMENTS}

This work was supported by the National Research Foundation of Korea (NRF) grant (No.2018R1D1A1B07050518) funded by the Ministry of Science and ICT, Republic of Korea; \& also supported by the Department of Animal Resources \& Science through the Research Focused Department Promotion Project as a part of the University Innovation Support Program for Dankook University in 2021.

\section{REFERENCES}

1. Zhu CL, Rademacher M, de Lange CFM. Increasing dietary pectin level reduces utilization of digestible threonine intake, but not lysine intake, for body protein deposition in growing pigs. J Anim Sci 2005;83:1044-53. https://doi.org/10.2527/ 2005.8351044x

2. Wang X, Qiao S, Yin Y, Yue L, Wang Z, Wu G. A deficiency or excess of dietary threonine reduces protein synthesis in jejunum and skeletal muscle of young pigs. J Nutr 2007;137: 1442-6. https://doi.org/10.1093/jn/137.6.1442

3. Kidd MT, Kerr BJ. L-threonine for poultry: a review. J Appl Poult Sci 1996;5:358-67. https://doi.org/10.1093/japr/5.4.358
4. Fuller MF, McWilliam R, Wang TC, Giles LR. The optimum dietary amino acid pattern for growing pigs. 2. Requirements for maintenance and for tissue protein accretion. Br J Nutr 1989;62:255-67. https://doi.org/10.1079/bjn19890028

5. Stoll B, Henry J, Reeds PJ, Yu H, Jahoor F, Burrin DG. Catabolism dominates the first-pass intestinal metabolism of dietary essential amino acids in milk protein-fed piglets. J Nutr 1998;128:606-14. https://doi.org/10.1093/jn/128.3.606

6. Sauer WC, Ozimek L. Digestibility of amino acids in swine: results and their practical applications. A review. Livest Prod Sci 1986;15:367-88. https://doi.org/10.1016/0301-6226(86)90 076-X

7. Knabe DA, La Reu DC, Greg EJ, Martinez GM, Tanksley TD. Apparent digestibility of nitrogen and amino acids in protein feedstuffs by growing pigs. J Anim Sci 1989;67:44158. https://doi.org/10.2527/jas1989.672441x

8. Schutte JB, de Jong J, Smink W, Koch F. Threonine requirement of growing pigs (50 to $95 \mathrm{~kg}$ ) in relation to diet composition. Anim Sci 1997;64:155-61. https://doi.org/10.1017/ S1357729800015666

9. Krizova L, Simecek M, Sustala M, Heger J. Optimum digestible threonine and sulphur amino acid requirements of high-lean growing pigs. Czech J Anim Sci 2001;46:489-95.

10.van Milgen J, Dourmad JY. Concept and application of ideal protein for pigs. J Anim Sci Biotechnol 2015;6:15. https://doi. org/10.1186/s40104-015-0016-1

11.van Lunen TA, Cole DJA. Energy-amino acid interactions in modern pig genotypes. In: Garnsworthy PC, Wiseman J, editor. Recent developments in pig nutrition 3. Nottingham, UK: Nottingham University Press; 2001.

12.Plitzner C, Ettle T, Windisch W. Experimental study on the requirement of threonine in finishing pigs. Bodenkultur 2006;57:161-8.

13.NRC (National Research Council). Nutrient requirements of swine, 11th rev. ed. Washington, DC, USA: National Academies Press; 2012.

14. AOAC International. Official methods of analysis. 17th ed. Washington, DC, USA: The Association of Official Analytical Chemists International; 2000.

15. Kim JI, Shon YG, Jung JH, Park YI. Genetic parameter estimates for backfat thickness at three different sites and growth rate in swine. Asian-Australas J Anim Sci 2004;17:305-8. https://doi.org/10.5713/ajas.2004.305

16.NPPC (National Pork Producers Council). Procedures to evaluate market hogs. 3rd edn. Des Moines, IA, USA: National Pork Production Council; 1991.

17. Kauffman RG, Eikelenboom G, van der Wal PG, Merkus G, Zaar M. The use of filter paper to estimate drip loss of porcine musculature. Meat Sci 1986;18:191-200. https://doi.org/10. 1016/0309-1740(86)90033-1

18. Sullivan ZM, Honeyman MS, Gibson LR, Prusa KJ. Effects of triticale-based diets on finishing pig performance and 
pork quality in deep-bedded hoop barns. Meat Sci 2007;76: 428-37. https://doi.org/10.1016/j.meatsci.2006.12.002

19. Honikel KO. Reference methods for the assessment of physical characteristics of meat. Meat Sci 1998;49: 447-57. https://doi. org/10.1016/S0309-1740(98)00034-5

20.Xie C, Zhang S, Zhang G, Zhang F, Chu L, Qiao S. Estimation of the optimal ratio of standardized ileal digestible threonine to lysine for finishing barrows fed low crude protein diets. Asian-Australas J Anim Sci 2013;26:1172-80. https:/doi.org/ 10.5713/ajas.2013.13045

21.Ma WF, Zeng XF, Liu XT, et al. Estimation of the standardized ileal digestible lysine requirement and the ideal ratio of threonine to lysine for late finishing gilts fed low crude protein diets supplemented with crystalline amino acids. Anim Feed Sci Technol 2015;201:46-56. https://doi.org/10.1016/j.anifeed sci.2014.09.025

22.van der Peet-Schwering CMC, Bikker P. Amino acid requirement of growing and finishing pigs. Wageningen, Netherlands: Wageningen Livestock Research; 2018. Report 1101.

23. Plitzner C, Ettle T, Handl S, Schmidt P, Windisch W. Effects of different dietary threonine levels on growth and slaughter performance in finishing pigs. Czech J Anim Sci 2007;52: 447-55.

24. Chen YP, Cheng YF, Li XH, et al. Effects of threonine supplementation on the growth performance, immunity, oxidative status, intestinal integrity, and barrier function of broilers at the early age. Poult Sci 2017;96:405-13. https://doi.org/10. 3382/ps/pew240

25. Min YN, Liu SG, Qu ZX, Meng GH, Gao YP. Effects of dietary threonine levels on growth performance, serum biochemical indexes, antioxidant capacities, and gut morphology in broiler chickens. Poult Sci 2017;96:1290-7. https://doi.org/10.3382/ ps/pew393

26. Dong XY, Azzam MMM, Zou XT. Effects of dietary threonine supplementation on intestinal barrier function and gut microbiota of laying hens. Poult Sci 2017;96:3654-63. https:// doi.org/10.3382/ps/pex185

27. Kobayashi H, Ishida A, Ashihara A, Nakashima K, Katsumata $M$. Effects of dietary low level of threonine and lysine on the accumulation of intramuscular fat in porcine muscle. Biosci Biotechnol Biochem 2012;76:2347-50. https://doi. org/10.1271/bbb.120589

28. Choi YS, Park BY, Lee JM, Lee SK. Comparison of carcass and meat quality characteristics between Korean native black pigs and commercial crossbred pigs. Korean J Food Sci Anim Resour 2005;25:322-7.

29. Kim GW, Im BS. Carcass grade and characteristics by carcass weight and backfat thickness of pigs. Korean J Food Sci Anim Resour 2006;26:183-8.

30.Larzul C, Lefaucheur L, Ecolan P, et al. Phenotypic and genetic parameters for longissimus muscle fiber characteristics in relation to growth, carcass, and meat quality traits in large white pigs. J Anim Sci 1997;75:3126-37. https://doi.org/10. 2527/1997.75123126x

31. Choi YS. Studies on the pork quality of Korean native black pigs and its improvement through dietary manipulation [dissertation]. Chuncheon, Korea: Kangwon National University; 2004.

32. Kim GW. Analysis of carcass quality grades according to gender, backfat thickness and carcass weight in pigs. J Anim Sci Technol 2012;54:29-33. https://doi.org/10.5187/JAST. 2012.54.1.29

33. Hah KH, Jin SK, Kim IS, Song YM, Lee JR, Chung KY. Pork quality characteristics by different backfat thickness. Korean J Food Sci Anim Resour 2005;25:391-6.

34. Han IK, Lee JH. The role of synthetic amino acids in monogastric animal production. Asian-Australas J Anim Sci 2000; 13:543-60. https://doi.org/10.5713/ajas.2000.543 